\title{
Warming drives sustained plant phosphorus demand in a humid tropical forest
}

\author{
Zhiyang Lie ${ }^{1}$, Wenjuan Huang ${ }^{2}$, kadowaki Kohmei ${ }^{3}$, Guoyi Zhou ${ }^{1}$, Junhua Yan ${ }^{1}$, Josep \\ Penuelas $^{4}$, Jordi Sardans ${ }^{5}$, David T. Tissue ${ }^{6}$, Yuelin Li ${ }^{1}$, Shizhong Liu ${ }^{1}$, Guowei Chu ${ }^{1}$, and \\ Juxiu $\mathrm{Liu}^{1}$ \\ ${ }^{1}$ South China Botanical Garden \\ ${ }^{2}$ Iowa State University \\ ${ }^{3}$ Kyoto University \\ ${ }^{4}$ CSIC-CREAF \\ ${ }^{5} \mathrm{CREAF}$ \\ ${ }^{6}$ Western Sydney University
}

June 9, 2021

\begin{abstract}
Phosphorus (P) is often one of the most limiting nutrients in highly weathered soils of humid tropical forests, which may regulate the responses of carbon (C) feedback to climate warming. Based on a 7-year continuous field warming experiment conducted by translocating microcosm forest ecosystems from a high-elevation site to low-elevation sites, we detected changes in the ecosystem $\mathrm{P}$ cycle in response to warming. We report that warming drives sustained plant $\mathrm{P}$ demand by increasing $\mathrm{P}$ uptake and thus decreasing foliar N:P. This increased plant $\mathrm{P}$ content is supplied by multiple processes including enhanced plant $\mathrm{P}$ resorption, soil $\mathrm{P}$ mineralization and dissolution without changing litter $\mathrm{P}$ mineralization and leachate $\mathrm{P}$. These findings suggest that warming may alleviate initial $\mathrm{P}$ deficiency and/or limitation of plant growth and contribute to sustaining plant $\mathrm{C}$ fixation in these tropical forests.
\end{abstract}

\section{Introduction}

Tropical forests account for approximately one-third of global terrestrial gross primary productivity and sequester one-half of global carbon (C) stored in terrestrial vegetation (Hubau et al., 2020). Climate models predict that tropics will experience earlier climate warming compared with other climatic regions (Mora et al., 2013). Consequently, large amounts of $\mathrm{C}$ stored in tropical forests may be lost by the warming induced release of carbon dioxide from soil due to enhanced microbial activity (Nottingham et al., 2019, 2020). However, it remains uncertain whether tropical forests will increase $\mathrm{C}$ storage above-ground in plant biomass to potentially compensate for $\mathrm{C}$ lost from soils under climate warming (Reed et al., 2012; Wieder et al., 2015). Phosphorus (P) status could be one of the most important factors determining $\mathrm{C}$ balance of tropical ecosystems under warming, as $\mathrm{P}$ often limits net primary production in the tropics (Cleveland et al., 2011; Du et al., 2020). If plants experience greater P limitation due to warming, then plant productivity and $\mathrm{C}$ fixation might be significantly reduced (Sullivan et al., 2020). Currently, incomplete understanding of $\mathrm{P}$ dynamics in tropical forests in response to warming is a challenge for modeling the direction and magnitude of tropical C feedback in future climates (Reed et al., 2015). 
The climate-demand/supply hypothesis holds that P limitation can be caused by high phosphorus demand and low phosphorus supply with climate change (Hou et al., 2021). Numerous studies have addressed plant P dynamics in response to warming (Sardans et al., 2006; Hood et al., 2018), and observed an elevated plant $\mathrm{P}$ demand due to increased plant production and P uptake (Rui et al., 2012; Diffenbaugh et al., 2013). To assess the potential for soil P supply under warming, most previous studies have focused on soil P availability (Sardans et al., 2006; Dijkstra et al. 2012). For instance, a decrease in plant-available P derived from the limited soil P mobility is observed with warming-induced drying soil (Dijkstra et al., 2012; Yuan \& Chen, 2015; Tian et al., 2018). Based on demand/supply hypothesis, enhanced plant P demand, but decreased soil $\mathrm{P}$ availability with warming may increase plant and microbial $\mathrm{P}$ deficiency (Jonasson et al., 2004). However, in P-deficient tropical ecosystems, focusing only on available $\mathrm{P}$ may lead to uncertainties regarding actual soil $\mathrm{P}$ supply since changes in available $\mathrm{P}$ can be masked by the balance of rapid soil $\mathrm{P}$ release and plants and/or microbes $\mathrm{P}$ uptake. These uncertain of $\mathrm{P}$ supply constrain our understanding on the status of plant $\mathrm{P}$ demand relative to $\mathrm{P}$ supply.

Combining key processes of $\mathrm{P}$ conversion and $\mathrm{P}$ fractions allows the assessment of $\mathrm{P}$ supply. The current paradigm states that tropical $\mathrm{P}$ cycling is dominated by $\mathrm{P}$ mineralization to meet rapid $\mathrm{P}$ turnover and plant demand (McGroddy et al., 2008; Turner et al., 2018). In general, warming tends to increase organic P mineralization by stimulating soil phosphatase production in optimal moisture environments (Zhou et al., 2013; Gong et al., 2015; Zi et al., 2018; Zuccarini et al., 2020), which further satisfies P demand during accelerated plant growth (Sardans et al., 2006; Rui et al., 2012). However, these studies ignore a important $\mathrm{P}$ supply process: plant $\mathrm{P}$ resorption that is a crucial strategy for plants to improve $\mathrm{P}$ use efficiency and reduce the dependence of plant growth on soil P availability (Vitousek et al., 1982; Yuan \& Chen, 2009). In resorption theory, the magnitude of plant $\mathrm{P}$ resorption is considered to be a trade-off with $\mathrm{P}$ derived from soil, especially from P mineralization (Vergutz et al., 2012; Gerdol et al., 2019). For instance, plants might retain adequate $\mathrm{P}$ concentrations in foliar tissues through increased plant $\mathrm{P}$ resorption when soil $\mathrm{P}$ availability is insufficient under warming (Yuan \& Chen, 2015; Zong et al., 2018). Consequently, in tropical forests with high plant productivity and low $\mathrm{P}$ availability in weathered soils, plant $\mathrm{P}$ resorption may play a critical role in $\mathrm{P}$ supply under warming. In addition, recent research found a previously unrecognized pathway of $\mathrm{P}$ supply: $\mathrm{P}$ bound to iron ( $\mathrm{Fe}$ ) oxides and hydroxides could be dissolved and released during redox fluctuations in humid tropical soils due to the enhanced metabolism and oxygen depletion of microbes and subsequently Fe reduction (Peretyazhko \& Sposito, 2005; Chacón et al., 2006; Gross et al., 2020). A reduced redox potential associated with $\mathrm{P}$ release from redox-sensitive dissimilatory reduction of Fe oxide-bound $\mathrm{P}$ was observed in a wetland ecosystem (Zhang et al., 2015). Although a large fraction of soil P may be bound to redox-sensitive Fe minerals in a humid tropical forest, significant portions of $\mathrm{P}$ might be released from Fe reduction due to increased microbial activity under warming ( $\mathrm{Li}$ et al., 2016). Moreover, the loss of $\mathrm{P}$ also affects $\mathrm{P}$ supply, but most studies ignore this fact, which prevents an accurate assessment of $\mathrm{P}$ cycling.

Most short-term warming cannot accurately anticipate $\mathrm{P}$ cycling dynamics at longer term (> 5 years), although from demand/supply hypothesis, tropical plants may be prone to experience more $\mathrm{P}$ limitation in long-term warming as $\mathrm{P}$ is continuously depleted with plant uptake and leaching. Lack of long-term monitoring in tropical forests indicates our incomplete understanding of the mechanisms controlling $\mathrm{P}$ cycling under long-term warming. To address these knowledge gaps, we conducted a 7-year field warming experiment in a humid tropical forest using natural temperature differences across elevations. We assessed $\mathrm{P}$ status in plant, litter, soil, and leachate as well as soil acid phosphatase and soil Fe components in the dry and wet seasons. Our previous studies found a continuous increase in plant growth and the accelerated decomposition of soil organic matter due to warming (Fang et al., 2020; Lie et al., 2021). Hence, we hypothesized that warming would increase plant $\mathrm{P}$ demand with enhanced plant growth, and $\mathrm{P}$ supply would be affected by multiple biological and geochemical processes which are strongly dependent on temperature.

\section{Materials and Methods}

\section{Site and treatments}

The study was conducted at the Dinghushan Biosphere Reserve in southern China (112 $10^{\prime}$ E, 23deg10'N). 
The reserve is characterized by a tropical monsoon humid climate with a mean annual temperature of 21 $\operatorname{deg} \mathrm{C}$ and mean relative humidity of $80 \%$. The mean annual precipitation of $1900 \mathrm{~mm}$ has a distinct seasonal pattern, with about $80 \%$ of it falling from April to September (warmer wet season) and $20 \%$ occurring from October to March (cooler dry season).

The experimental warming site was constructed by translocating the microcosm forest ecosystem from the high-elevation site (control: $600 \mathrm{~m}$ ) to low-elevation sites (+1.0degC treatment: $300 \mathrm{~m}$; $+2.1 \mathrm{degC}$ treatment: $30 \mathrm{~m}$ ) (Fig. S1). In May 2012, three plots (open-top chambers; $3 \mathrm{~m}$ length $\mathrm{x} 3 \mathrm{~m}$ width $\mathrm{x} 0.8 \mathrm{~m}$ depth) were established at each of the elevation sites, representing three replicates of each temperature treatment. Each belowground plot was surrounded by concrete brick wall bonding with ceramic tile, with one hole connected with PVC tubing at the bottom and the top of the chamber wall to collect underground water and surface runoff, respectively. All plots were separated by a $3 \mathrm{~m}$ buffer zone. Before planting, we collected soil from each of the three horizons $(0-20,20-40$, and $40-70 \mathrm{~cm})$ in the adjacent naturally occurring mountain evergreen broad-leaved forest, and homogenized each layer separately, and then placed each soil horizon into each plot. Six one-year old dominant plant species, including arbuscular mycorrhiza-forming species (Schima superba, Itea chinensis, Machilus breviflora, Myrsine seguinii, and Ardisia lindleyana) and only one ectomycorrhiza-forming species (Syzygium rehderianum) at an elevation of $600 \mathrm{~m}$ in the natural forest, were collected and then randomly planted in each plot (six individuals per species). Four $0.2 \mathrm{~m} \mathrm{x} 0.2 \mathrm{~m}$ litter traps were placed randomly in each plot. One tree per species was randomly harvested in December 2014, December 2015, and June 2018 to avoid crowding in the chambers.

Soil temperature and soil volumetric water content at $5 \mathrm{~cm}$ soil depth were measured in each plot using Campbell 109 constantan-copper thermocouples and time-domain reflectometer probes (CS616, Campbell, USA), respectively. Data were recorded every 30 min using Campbell Scientific (Logan, UT, USA) CR1000 data loggers. Further detailed information regarding the experimental site was described in Lie et al., (2021).

\section{Sample collection and processing}

Twenty to thirty leaves were randomly collected per species (S. superba, S. rehderianum, I. chinensis and $M$. breviflora ; the remaining two species were excluded because of their small biomass with less than $1.1 \%$ of the total biomass) for each plot in the dry season and wet seasons from 2013-2019. In 2014, 2015, and 2017-2019, monthly litter samples in each plastic net were collected. In December 2017 and 2018 and June 2018 and 2019, soil samples were collected with five replicates per soil depth (0-10, 10-20, 20-40 cm depth) for each plot using a 3.5-cm-diameter stainless steel soil corer and then were pooled by each plot. Soil bulk density was measured using the cutting-ring method. Soil samples were sieved through a 2-mm mesh and then stored at $4 \mathrm{degC}$. All plant samples were oven-dried at $60 \operatorname{degC}$ for at least $24 \mathrm{~h}$ before being weighed. Soil $\mathrm{pH}$ was measured at a soil-to-water ratio of 1:2.5.

\section{$\mathbf{P}$ status in plant, litter, soil and leachate}

The $\mathrm{P}$ concentrations of plant and litter were measured photometrically after digestion with $\mathrm{H}_{2} \mathrm{SO}_{4}$ $\mathrm{H}_{2} \mathrm{O}_{2}$ (Anderson \& Ingram, 1989). Total plant $\mathrm{P}$ uptake was calculated by the sums of tissue biomass multiplied by corresponding P concentrations of the four species. Soil microbial biomass $\mathrm{P}$ were analyzed using the fumigation-extraction method (Vance et al., 1987): a subsample was extracted using $0.03 \mathrm{M} \mathrm{NH}_{4} \mathrm{~F}$ and $0.025 \mathrm{M} \mathrm{HCl}$ to determine extracted $\mathrm{P}$, and another subsample was fumigated for $24 \mathrm{~h}$ with chloroform and extracted with the same extract. The extracted $\mathrm{P}$ concentrations were corrected for the sorption of $\mathrm{P}$ to soil particles during extraction based on the difference between samples spiked and not spiked with $\mathrm{P}(25$ $\mu \mathrm{g}$ of inorganic $\mathrm{P}$ added as $\left.\mathrm{KH}_{2} \mathrm{PO}_{4}\right)$. The microbial biomass $\mathrm{P}$ values were calculated as the differences between the values of fumigated and un-fumigated subsamples corrected by the conversion factor (i.e., 0.4).

Soil P fractionation was measured according to the method described by Tiessen \& Moir (1993) and McDowell \& Condron (2000). The $\mathrm{P}$ in soil was sequentially extracted by $1.0 \mathrm{M} \mathrm{NH}_{4} \mathrm{Cl}$ (soluble $\mathrm{P}$ ), $0.1 \mathrm{M} \mathrm{NH}_{4} \mathrm{~F}$ (aluminum phosphate, Al-P), $0.1 \mathrm{M} \mathrm{NaOH}$ (ferric phosphate, Fe-P). The non-extracted $\mathrm{P}$ in soils after sequential extraction was residual $\mathrm{P}$ (occluded P). In brief, $3.0 \mathrm{~g}$ of finely ground air-dried soil was extracted by $30 \mathrm{~mL}$ of each extractant solution on a horizontal shaker. The shaking time was $30 \mathrm{~min}$ for $\mathrm{NH}_{4} \mathrm{Cl}, 16$ 
h for $\mathrm{NH}_{4} \mathrm{~F}$ and $\mathrm{NaOH}$. The solution after shaking was centrifuged at 10,000 r/min for $10 \mathrm{~min}$ to collect supernatant for inorganic and total $\mathrm{P}$ analysis. Phosphorus extracted by $\mathrm{NH}_{4} \mathrm{Cl}$ was classified as easilyavailable $\mathrm{P}$, while $\mathrm{P}$ in $\mathrm{NH}_{4} \mathrm{~F}$ and $\mathrm{NaOH}$ extracts was classified as moderately-available $\mathrm{P}$. The organic $\mathrm{P}$ concentration in $\mathrm{NH}_{4} \mathrm{~F}$ and $\mathrm{NaOH}$ extracts were calculated as the difference between total $\mathrm{P}$ analyzed after persulphate digestion and inorganic $\mathrm{P}$. The moderately-available organic $\mathrm{P}$ was the sums of organic $\mathrm{P}$ extracted by $\mathrm{NH}_{4} \mathrm{~F}$ and $\mathrm{NaOH}$. All soil extracted $\mathrm{P}$ was determined using an inductively coupled plasma optical emission spectrometer (ICP-OES; Optima 2000 DV, Perkin Elmer, USA).

Leachate $\mathrm{P}$ concentrations were measured colorimetrically. Total leachate $\mathrm{P}$ was calculated by summing both surface and underground soil solutions, after multiplying $\mathrm{P}$ concentrations by the leachate volume, in each month. Rainfall was similar among treatments throughout the experiment due to similar slope aspects and close distance across the three sites.

\section{Acid phosphates activity and mycorrhizal fungi}

We used colorimetric methods to analyze acid phosphates activity (Tabatabai, 1994). Specifically, four grams of moist soil or 0.2 grams of litter was added with $60 \mathrm{ml}$ of $50 \mathrm{mM}$ acetate buffer (pH 5) in a blender for 1 min. A subsample $(0.75 \mathrm{ml})$ of the slurry was then added to $0.75-\mathrm{ml}$ substrate $(5 \mathrm{mM})$. Two controls (buffer + substrate and buffer + slurry subsample) were also analyzed. Each analysis was repeated three times. After $1 \mathrm{~h}$ incubation at $20^{\circ} \mathrm{C}$ in the dark, each sample was centrifuged at $2091 \times \mathrm{g}$, then $0.2 \mathrm{ml}$ of supernatant was transferred into a 96-well plate. Finally, $0.03 \mathrm{ml}$ ultrapure water and $0.02 \mathrm{ml} 1 \mathrm{M} \mathrm{NaOH}$ were added to each well. Absorbance of each well was measured at $405 \mathrm{~nm}$ by Multiskan EX (Thermo Scientific, Waltham, $\mathrm{MA})$. A p-nitrophenol ( $p$-NP) calibration curve was performed, and results were expressed in $\mu \mathrm{mol}$ of $p$-NP released $\mathrm{h}^{-1} \mathrm{~g}^{-1}$ of dry soil.

PLFA assays were performed using established methods to estimate the abundance of arbuscular mycorrhizal fungi (16:1 $\omega 5 \mathrm{c})$ and ectomycorrhizal fungi $(18: 2 \omega 6)(65)$. In brief, lipids were extracted from $8 \mathrm{~g}$ of lyophilized soil, fractionated and methylated. The resulting fatty acid methyl esters (FAMEs) were separated using a GC gas chromatograph (Agilent GC7890A; Agilent Technologies Inc.). Peaks were identified using the Sherlock System (v. 6.1; MIDI Inc.).

\section{Soil Fe minerals}

Two assays were used to quantify redox-sensitive soil Fe pools (Liptzin \& Silver, 2009; Huang \& Hall, 2017). First, we used a hydrochloric acid ( $\mathrm{HCl}$ ) extraction to solubilize reactive $\mathrm{Fe}(\mathrm{II})$ and total solubilize reactive $\mathrm{Fe}_{\mathrm{HCl}}[\mathrm{Fe}(\mathrm{II})+\mathrm{Fe}(\mathrm{III})]$ from short-range order and organo-Fe complexes; $3.75 \mathrm{~g}$ fresh soil was extracted in $30 \mathrm{~mL} 0.5 \mathrm{M} \mathrm{HCl}$ solution. The concentrations of Fe(II) and Fe(III) were analyzed colorimetrically. Second, we used citrate-ascorbate to extract chelatable short-range order (oxy) hydroxides and organo-Fe complexes $\left(\mathrm{Fe}_{\mathrm{ca}}\right)$. This pool is generally defined as reducible amorphous or poorly crystalline Fe (Hall \& Silver, 2015). To estimate $\mathrm{Fe}_{\mathrm{ca}}, 1.25 \mathrm{~g}$ fresh soil subsamples were added to the freshly prepared citrate-ascorbate solution in a 1:30 ratio, vortexed, and then shaken in the dark for $16 \mathrm{~h}$. Then, the samples were centrifuged at 10,000 $\mathrm{r} / \mathrm{min}$ for $10 \mathrm{~min}$ and the supernatant solution was measured using ICP-OES. Higher $\mathrm{Fe}(\mathrm{II})_{\mathrm{HCl}}$ : $\mathrm{Fe}_{\mathrm{HCl}}$ and $\mathrm{Fe}_{\text {ca }}$ can be good indicators of reducing conditions in humid tropical forest soils (Liptzin \& Silver, 2015). To determine total free $\mathrm{Fe}\left(\mathrm{Fe}_{\mathrm{cd}}\right)$, Fe was measured in citrate-dithionite extractions at a 1:60 dry soil-to-solution ratio.

\section{Statistical Analyses}

Whole plot average plant biomass, foliar $\mathrm{P}$ concentration and N:P ratio were calculated using a weighting factor for each species, which was estimated by determining the average basal diameter of each species from 2013 to 2019. Foliar N concentrations were originally presented in Lie et al., (2021). Plant P uptake was estimated by the weighted sum of $\mathrm{P}$ accumulated by the four species (data from Wu et al., 2020). Plant $\mathrm{P}$ resorption efficiency was calculated as $\left(1-\mathrm{P}_{1} / \mathrm{P}_{\mathrm{f}} \times \mathrm{MLCF}\right) \times 100 \%$, where $\mathrm{P}_{1}$ is litter $\mathrm{P}$ concentrations and $\mathrm{P}_{\mathrm{f}}$ is the weighted foliar $\mathrm{P}$ concentrations of the four species; MLCF is the mass loss correction factor, which is 0.78 for evergreen broad-leaved forest tree species (Vergutz et al., 2012). 
Differences in P status in plant, soil and leachate, as well as soil phosphatase activity and soil Fe minerals under treatment were analyzed using linear mixed-effects model. Warming treatment and experimental time were treated as fixed factors, while plot was treated as a random factor. Pairwise comparisons of means were tested by Least Significant Difference test. Data were transformed to meet the assumptions of normality and homogeneity of variances when necessary. Statistical significance was defined as $P<0.05$. Linear mixed models were performed by "lmer" function in "lme4" package (Bates et al., 2015) using R version 3.6.1.

\section{Results}

\section{Soil temperature, moisture, $\mathrm{pH}$, redox potential, and bulk density}

Throughout the experiment of 2013-2019, the average monthly soil temperatures at $5 \mathrm{~cm}$ depth were significantly increased by $1.0 \pm 0.1^{\circ} \mathrm{C}$ and $2.1 \pm 0.1^{\circ} \mathrm{C}$ for the mid-elevation site and the low-elevation treatments (hereafter we refer to them as $+1.0^{\circ} \mathrm{C}$ treatment and $+2.1^{\circ} \mathrm{C}$ treatment respectively) relative to the control $\left(19.7 \pm 0.6^{\circ} \mathrm{C}\right.$ on average; $P<0.01$; Fig. S2a). Compared with the control $(18.9 \pm 0.3 \% \mathrm{v} / \mathrm{v})$, the average monthly soil moisture at 5 -cm depth was significantly decreased in the $+2.1^{\circ} \mathrm{C}$ treatment $(-3.8 \% \mathrm{v} / \mathrm{v} ; P<$ 0.01 ), but was not changed in the $+1.0^{\circ} \mathrm{C}$ treatment across the whole experiment (Fig. S2b). In-site soil redox potential at 10-cm depth was decreased by $39.1 \pm 24.9 \mathrm{mV}$ in the $+2.1^{\circ} \mathrm{C}$ treatment during $2017-2019$ $(P<0.05)$, with no interaction between warming treatments and experimental times (Table S1). Warming had no significant effects on soil $\mathrm{pH}$ and soil bulk density in the topsoil $(0-10 \mathrm{~cm})$.

\section{Plant $\mathbf{P}$ status}

During the period of 2013-2019, foliar N:P at ecosystem level in the control averaged 23.8 \pm 0.6 . In each treatment, foliar N:P was negatively correlated with foliar P concentration but was uncorrelated with foliar $\mathrm{N}$ concentration (Fig. S3). In the $+2.1^{\circ} \mathrm{C}$ treatment, foliar N:P was significantly decreased by $4.7 \pm 1.5 \%$ without changing foliar $\mathrm{P}$ concentrations throughout the experiment $\left(P<0.05\right.$; Fig. 1a, b). The $+2.1^{\circ} \mathrm{C}$ treatment significantly increased $\mathrm{P}$ concentrations by $23.4 \pm 4.3 \%$ in stems, $14.4 \pm 5.0 \%$ in fine roots and $32.4 \pm 6.2 \%$ in coarse roots in $2018(P<0.05)$, but it did not affect tissue $\mathrm{P}$ concentrations in 2015 (Fig. S4a). The $+2.1^{\circ} \mathrm{C}$ treatment significantly increased fine roots and decreased abundance of arbuscular mycorrhizal fungi in 2015, but it had no effect on these in 2018 (Fig. S4b, c).

Plant P uptake was significantly increased in both 2015 and 2018 under warming $\left(33.8 \pm 7.4 \%\right.$ in the $+1.0^{\circ} \mathrm{C}$ treatment and $90.6 \pm 11.8 \%$ in the $+2.1^{\circ} \mathrm{C}$ treatment on average; Fig. 1c). During 2014-2015 and 2017-2019, plant $\mathrm{P}$ resorption efficiency was significantly increased by $5.8 \pm 2.9 \%$ in the $+2.1^{\circ} \mathrm{C}$ treatment relative to the control $(56.8 \pm 2.3 \%$ on average) (Fig. 1d). Plant resorption was negatively correlated to foliar $\mathrm{P}$ concentrations, soil $\mathrm{NH}_{4} \mathrm{Cl}-\mathrm{P}$ concentrations, and soil moisture (Fig. S5). Litter C:P was significantly increased by $26.0 \pm 9.7 \%$ in the $+2.1^{\circ} \mathrm{C}$ treatment during $2017-2019(P<0.01$; Table S2). Litter $\mathrm{P}$ stock and litter phosphatase activity were not changed under warming during 2017-2019.

\section{$\mathbf{P}$ status in soil and leachate}

In the control, relative $\mathrm{P}$ components were $\mathrm{Fe}-\mathrm{Pi}>\mathrm{Fe}-\mathrm{Po}>\mathrm{Al}-\mathrm{Pi}, \mathrm{Al}-\mathrm{Po}>$ soluble $\mathrm{P}$ in the three layers of soils, and $\mathrm{Fe}-\mathrm{Pi}$ accounted for at least $50 \%$ of easily-available $\mathrm{P}$ and moderately-available $\mathrm{P}$ components (soluble $\mathrm{P}+\mathrm{Al}-\mathrm{Pi}+\mathrm{Al}-\mathrm{Po}+\mathrm{Fe}-\mathrm{Pi}+\mathrm{Fe}-\mathrm{Po}$; Table S3, Fig. 2). With both warming treatments, the soluble $\mathrm{P}$ concentrations and microbial biomass $\mathrm{P}$ were not changed (Table S3). However, the $+2.1^{\circ} \mathrm{C}$ treatment significantly decreased moderately-available organic P concentrations in $0-10 \mathrm{~cm}$ soil depth by $15.5 \pm 7.3 \%$ $(P<0.05)$ relative to the control $\left(28.4 \pm 1.5 \mathrm{mg} \mathrm{kg}^{-1} ;\right.$ Fig. $\left.2 \mathrm{a}\right)$. The Fe-Pi concentrations were significantly decreased by $+2.1^{\circ} \mathrm{C}$ treatment in $0-10 \mathrm{~cm}$ soil depth by $6.8 \pm 2.7 \%$ relative to the control $(34.0 \pm 0.8 \mathrm{mg}$ $\mathrm{kg}^{-1}$ ), while Al-Pi concentrations were not changed by warming (Fig. 2b, Table S3). There was no significant response of moderately-available organic $\mathrm{P}$ and Fe-Pi to warming in the deeper soils $(10-20 \mathrm{~cm}$ and $20-40$ $\mathrm{cm})$. Soil potential acid phosphatase activity in all three depths was significantly increased in the $+2.1^{\circ} \mathrm{C}$ treatment $(P<0.05$, Fig. 3a). 
Averaged monthly total leachate $\mathrm{P}$ in the control was $0.02 \mathrm{~kg} \mathrm{hm}^{-2}$ month$^{-1}$ during 2013-2019 (Fig. 4). Warming had no significant effect on total leachate $\mathrm{P}$ throughout the experiment. However, relative to the control, leachate $\mathrm{P}$ of surface runoff was decreased by $55.0 \pm 37.4 \%$ in the $+2.1^{\circ} \mathrm{C}$ treatment, while leachate $\mathrm{P}$ in underground water was increased by $+21.4 \pm 9.2 \%$ and $36.8 \pm 11.2 \%$ in the $+1.0^{\circ} \mathrm{C}$ and $+2.1^{\circ} \mathrm{C}$ treatments, respectively. There was no significant interaction between warming treatments and times.

\section{Soil Fe minerals}

During $2017-2019$, The $+2.1^{\circ} \mathrm{C}$ treatment significantly increased $\mathrm{Fe}(\mathrm{II})_{\mathrm{HCl}}: \mathrm{Fe}_{\mathrm{HCl}}$ in three depths $(P<0.05)$. Soil $\mathrm{Fe}_{\mathrm{ca}}$ concentrations were significantly elevated in soil depth of $0-10 \mathrm{~cm}(P<0.05)$, but were not changed in the deeper soils $(10-20$ and $20-40 \mathrm{~cm})$ in the $+2.1^{\circ} \mathrm{C}$ treatment. There was no significant difference of $\mathrm{Fe}_{\mathrm{cd}}$ concentration between control and warming treatments (Table S3). There were no significant interactions between warming treatments and seasons on $\mathrm{Fe}(\mathrm{II})_{\mathrm{HCl}}: \mathrm{Fe}_{\mathrm{HCl}}, \mathrm{Fe}_{\mathrm{ca}}$ and $\mathrm{Fe}_{\mathrm{cd}}$ concentrations.

\section{Discussion}

We examined $\mathrm{P}$ dynamics in the plant, soil and leachate in a humid tropical forest exposed to 7-year of continuous field warming. Contrary to most studies which show that short-term warming increases ecosystem $\mathrm{P}$ deficiency in arid ecosystems or large scales (Jonasson et al., 2004; Yuan \& Chen, 2015), we found that warming by $2.1^{\circ} \mathrm{C}$ increased plant $\mathrm{P}$ uptake and decreased foliar $\mathrm{N}: \mathrm{P}$, indicating warming drove sustained plant $\mathrm{P}$ demand and may alleviate $\mathrm{P}$ deficiency and/or limitation of enhanced plant growth and contribute to sustaining plant $\mathrm{C}$ fixation in these tropical forests. It is worth pointing out that the sustained plant $\mathrm{P}$ demand could not be explained by traditional views in accessing $\mathrm{P}$ acquisition (through fine root and mycorrhizal fungi; Rosling et al., 2016) and supply (through $\mathrm{P}$ availability), because neither fine root biomass nor arbuscular mycorrhizal fungi abundance were affected by 6 -year warming as they were by short-term warming (Lie et al., 2021), and soil soluble P had no response to warming.

We observed a enhanced $\mathrm{P}$ redistribution capacity and soil $\mathrm{P}$ mobilization to support increasing plant $\mathrm{P}$ demand without altering litter $\mathrm{P}$ mineralization and leachate $\mathrm{P}$, which led to a net transfer of $\mathrm{P}$ from soil to plant regulated by biogeochemical processes (Fig. 5): (1) warming increased plant $\mathrm{P}$ resorption by $4.7 \%$, which enhanced plant $\mathrm{P}$ recycling and soil P inputs; (2) warming elevated soil P mineralization by $15.4 \%$ and dissolution by $6.8 \%$ in the topsoil, thereby improving soil $\mathrm{P}$ supply; (3) reduced $\mathrm{P}$ loss in surface runoff under warming facilitated $\mathrm{P}$ retention for topsoil and shallow roots. Our findings improved the understanding of biogeochemical controls on plant $\mathrm{P}$ acquisition under warming, which are crucial to project the future $\mathrm{C}$ sequestration potential of tropical ecosystems that are mostly limited by P (Fig.1; foliar N:P > 20) (Güsewell, 2004; Cleveland et al., 2013).

Plant $\mathrm{P}$ resorption increased under warming, similar to observations at the global scale that plant $\mathrm{P}$ resorption was positively correlated with temperature (Yuan \& Chen, 2009; You et al., 2018). Plant growth periods strongly drive plant nutrient resorption (Sun et al., 2016). A warming experiment conducted in subtropical forests showed that foliar growth periods were extended by an average of $5-18$ days at $2^{\circ} \mathrm{C}$ of warming (Gunderson et al., 2013). Thus, warming potentially delays foliar senescence (Chung et al., 2013) and consequently increases foliar plant $\mathrm{P}$ resorption (Estiarte \& Peñuelas, 2015). Moreover, it is noted that plant $\mathrm{P}$ resorption increased with $\mathrm{P}$ supply derived from soil (i.e.,enhanced $\mathrm{P}$ mineralization and dissolution) under warming, which contradicts the view on a trade-off between nutrient resorption and soil nutrient supply (Vergutz et al., 2012; Gerdol et al., 2019). We found that increased P resorption was likely driven by warming-induced drying soil (Fig. S5), which is consistent with a study in a dry ecosystem (Ren et al., 2018). P resorption increases $\mathrm{P}$-use efficiency in plants via higher $\mathrm{P}$ productivity and longer residence time of $\mathrm{P}$, while new roots may be limited in the capacity to take up $\mathrm{P}$ from litter in drier soil. Thus, an increase in plant $\mathrm{P}$ resorption may be a more economical $\mathrm{P}$ acquisition strategy than increased investment in roots. These findings extend the application of resorption theory to $\mathrm{P}$ cycling, and also highlight the key $\mathrm{P}$ source from resorption for plants under warming. 
Most studies reported that $\mathrm{P}$ mineralization in humid forest soils was enhanced under warming (Rui et al., 2012; Zhou et al., 2013; Zi et al., 2018; Zuccarini et al., 2020). Consistent with these studies, warming elevated soil $\mathrm{P}$ mineralization by increasing soil potential acid phosphatase activity and decreasing moderately-available organic $\mathrm{P}$ in topsoil. The elevated soil $\mathrm{P}$ mineralization could be driven by joint increases in plant demand for $\mathrm{P}$ and microbial activity (e.g., higher soil respiration ( $\mathrm{Li}$ et al., 2016)). The increase in soil acid phosphatase activity could be stimulated by microbes to compensate for the reduction of $\mathrm{P}$ diffusion in warming-induced drying soil (Allison et al., 2010) and the limitation of microbial $\mathrm{P}$ utilization during litter decomposition with higher litter C:P (Table S3; Sardans et al., 2006). Our data thus showed that more $\mathrm{P}$ was retained in plants than returned to soil in each litter cycle under warming, which led to a net transfer of $\mathrm{P}$ from soil moderately-available organic $\mathrm{P}$ to the plant.

At our site, a large fraction of the moderately-available $\mathrm{P}$ in the soils was in inorganic form ( $>58 \%)$, suggesting that inorganic $\mathrm{P}$ dissolution may be especially important for $\mathrm{P}$ supply. In line with our hypothesis, warming enhanced $\mathrm{P}$ dissolution, as evidenced by lower Fe-Pi in the topsoil. However, the Al-Pi and $\mathrm{pH}$ in the three soil depths were not affected by warming, suggesting that the decrease in Fe-Pi was not caused by soil $\mathrm{pH}$, which served as a critical factor of P dissolution (Navratil, et al., 2009; Devau et al., 2011). Rather, the lower Fe-Pi was likely related to sensitive changes of soil Fe phases under warming. In topsoil, warming led to decreases in redox potential and increases in both $\mathrm{Fe}(\mathrm{II})_{\mathrm{HCl}}: \mathrm{Fe}_{\mathrm{HCl}}$ and $\mathrm{Fe}_{\mathrm{ca}}$ concentrations, indicating higher Fe reduction. Our finding challenges the prevailing expectation that warming drives more oxidative soil, due to increased soil porosity by warming-induced drying soil (Wang et al., 2017). The higher Fe reduction probably was due to the enhanced microbial activity, root respiration coupled to higher $\mathrm{P}$ uptake capacity and thus oxygen depletion under warming at our site (Li et al., 2016). Compared with $\mathrm{Al}$ minerals, the reduction of $\mathrm{Fe}$ minerals is considered to effectively reduce geochemical sequestration of easily-available $\mathrm{P}$ to increase soluble P and even alleviate P limitation in humid tropical soils (Chacón et al., 2006; Lin et al., 2018; Gross et al., 2020). Some studies in subtropical wetland systems have reported similar declines in redox potential and increases in P release from Fe minerals under warming (Zhang et al., 2012; Wang et al., 2013). Accordingly, the increases in $\mathrm{P}$ release can elevate soil soluble $\mathrm{P}$, as observed in incubation experiments with higher soluble P under reducing conditions (Peretyazhko \& Sposito, 2005; Wang et al., 2017). However, we did not find changes in soil soluble $\mathrm{P}$, which might suggest a rapidly attained equilibrium, in which soluble $\mathrm{P}$ induced from the dissolution of Fe-Pi was rapidly taken up by plants in this P-poor system (Liptzin \& Silver, 2009). The rapid plant uptake could prevent potential $P$ re-immobilization and loss by leaching. Overall, the increase in $\mathrm{P}$ release from Fe minerals provides evidence for greater soil $\mathrm{P}$ supply under warming, which was expected to facilitate plant $\mathrm{P}$ utilization.

The losses of $\mathrm{P}$ deserve to be noticed under warming. $\mathrm{P}$ in terrestrial ecosystems is primarily lost through leachate that makes it difficult its return to the system. Currently, global P mineable reserves are gradually being lost from ecosystems due to improper use of $\mathrm{P}$ fertilizers in forest and farmland managements. Greater plant $\mathrm{P}$ uptake generally promotes $\mathrm{P}$ fixation in plants and thereby potentially reduces $\mathrm{P}$ loss. Intriguingly, we noted that the increased plant $\mathrm{P}$ uptake does not imply less $\mathrm{P}$ losses, because the net $\mathrm{P}$ losses were counterbalanced by the decreased $\mathrm{P}$ losses in surface runoff and the increased $\mathrm{P}$ losses in underground water. These results suggest that warming shifts $\mathrm{P}$ loss from surface to subsurface, and emphasizes the necessity to assess effects of warming on $\mathrm{P}$ dynamics at the ecosystem level.

Our study provides new insights into understanding tropical $\mathrm{P}$ cycling processes and modelling forest $\mathrm{P}$ limitation under warming. The findings of the sustained plant $\mathrm{P}$ demand driven by increasing $\mathrm{P}$ supplies through multiple biological and geochemical processes within the ecosystems (e.g., plant $\mathrm{P}$ resorption, soil $\mathrm{P}$ mineralization, and $\mathrm{P}$ release from Fe minerals) under warming extend the traditional assessment method (measure $\mathrm{P}$ supply by available/soluble $\mathrm{P}$ ) and the current paradigm states (assess $\mathrm{P}$ conversation only by soil $\mathrm{P}$ mineralization). This suggests that previous studies may have overestimated the impacts of $\mathrm{P}$ limitation on ecosystem $\mathrm{C}$ stock under at least short-term or medium-term future warming (Wieder et al., 2015). Our study also provides additional information on $\mathrm{P}$ dynamics that can be incorporated into earth system models which require further quantification (Reed et al., 2015; Sun et al., 2017). 


\section{Conclusion}

Our 7-year field warming study demonstrated that warming led to a net transfer of soil P from moderatelyavailable organic $\mathrm{P}$ and $\mathrm{Fe}-\mathrm{Pi}$ to the plant without altering litter $\mathrm{P}$ mineralization and ecosystem $\mathrm{P}$ loss. Warming thus increases the plant biological "control" of the plant-soil P-cycle, increasing the stocks of $\mathrm{P}$ involved in the fast $\mathrm{P}$ plant-soil cycle and plant $\mathrm{P}$-use efficiency (higher C:P ratio in litter). The results suggest that warming changed net balance of plant-P cycle through multiple processes (the enhanced plant $\mathrm{P}$ resorption, soil $\mathrm{P}$ mineralization and dissolution) rather than in single form or process, which extends our previous understanding of the climate-demand/supply hypothesis and the application of nutrient resorption theory and emphasizes the assessment of $\mathrm{P}$ dynamics at the ecosystem level. In this humid tropical forest under warming, greater $\mathrm{P}$ supply to support higher mass production is expected than previous prediction via short-term experiments or studies with single evaluation, and moderate warming may alleviate current $\mathrm{P}$ deficiency and/or limitation in tropical plants and contribute to greater plant $\mathrm{C}$ fixation in a warmer future climate.

\section{Acknowledgement}

We thank Kanehiro Kitayama for providing us many thoughtful and constructive comments. This study was funded by the National Natural Science Foundation of China (Grant Nos. 41991285, 41977287, 41825020 and 31961143023), Key Research and Development Program of Guangdong Province (2020B1111530004) and the Science and Technology Programs of Guangzhou City (Grant No. 201903010021). The authors declare no conflict of interests.

\section{Reference}

Allison, S. D., Weintraub, M. N., Gartner, T. B., \& Waldrop, M. P. (2010). Evolutionary-economic principles as regulators of soil enzyme production and ecosystem function. In Soil enzymology (pp. 229-243). Springer, Berlin, Heidelberg.

Anderson, J.M., \& Ingram, J. (1989). Tropical soil biology and fertility. CAB International, Wallingford.

Bates, D., Mächler, M., Bolker, B., \& Walker, S. (2015). Fitting linear mixed-effects models using lme4. J. Stat. Softw. ,67, 1-48.

Chacon, N., Silver, W. L., Dubinsky, E. A., \& Cusack, D. F. (2006). Iron reduction and soil phosphorus solubilization in humid tropical forests soils: the roles of labile carbon pools and an electron shuttle compound. Biogeochemistry, $\mathbf{7} \mathbf{8}, 67-84$.

Cheeke, T.E., Phillips, R.P., Brzostek, E.R., Rosling, A., Bever, J.D., \& Fransson, P. (2017). Dominant mycorrhizal association of trees alters carbon and nutrient cycling by selecting for microbial groups with distinct enzyme function. New Phytol., $214,432-442$.

Chung, H., Muraoka, H., Nakamura, M., Han, S., Muller, O., \& Son, Y. (2013). Experimental warming studies on tree species and forest ecosystems: a literature review. J. Plant Res. , 126 , 447-460.

Cleveland, C. C., Houlton, B. Z., Smith, W. K., Marklein, A. R., Reed, S. C., Parton, W., et al.(2013). Patterns of new versus recycled primary production in the terrestrial biosphere. P. Natl. Acad. Sci ., 110 , 12733-12737.

Cleveland, C. C., Townsend, A. R., Taylor, P., Alvarez-Clare, S., Bustamante, M. M., Chuyong, G., et al.(2011). Relationships among net primary productivity, nutrients and climate in tropical rain forest: a pan-tropical analysis. Ecol. lett. , 14, 939-947.

Devau, N., Hinsinger, P., Le Cadre, E., Colomb, B., \& Gérard, F.(2011). Fertilization and pH effects on processes and mechanisms controlling dissolved inorganic phosphorus in soils. Geochim.Cosmochim.Ac. $\mathbf{7 5}$, 2980-2996. 
Diffenbaugh, N. S., \& Field, C. B. (2013). Changes in ecologically critical terrestrial climate conditions. Science, $\mathbf{3 4 1}$, 486-492.

Dijkstra, F. A., Pendall, E., Morgan, J. A., Blumenthal, D. M., Carrillo, Y., LeCain, D. R., et al. (2012). Climate change alters stoichiometry of phosphorus and nitrogen in a semiarid grassland. New Phytol. , 196 , 807-815.

Du, E., Terrer, C., Pellegrini, A. F., Ahlström, A., van Lissa, C. J., Zhao, X., et al. (2020). Global patterns of terrestrial nitrogen and phosphorus limitation. Nat. Geosci.13, 221-226.

Estiarte, M., \& Peñuelas, J. (2015). Alteration of the phenology of leaf senescence and fall in winter deciduous species by climate change: effects on nutrient proficiency.Global Change Biol. ,21 , 1005-1017.

Fang, X., Zhou, G., Qu, C., Huang, W., Zhang, D., Li, Y., et al . (2020). Translocating subtropical forest soils to a warmer region alters microbial communities and increases the decomposition of mineral-associated organic carbon. Soil Biol. Biochem. ,142, 107707.

Gerdol, R., Iacumin, P., \& Brancaleoni, L. (2019). Differential effects of soil chemistry on the foliar resorption of nitrogen and phosphorus across altitudinal gradients. Funct. Ecol.33 , 1351-1361.

Gong, S., Zhang, T., Guo, R., Cao, H., Shi, L., Guo, J., \& Sun, W. (2015). Response of soil enzyme activity to warming and nitrogen addition in a meadow steppe. Soil Res. 53, 242-252.

Gross, A., Lin, Y., Weber, P. K., Pett-Ridge, J., \& Silver, W. L (2020). The role of soil redox conditions in microbial phosphorus cycling in a humid tropical forest. Ecology ,101, e02928.

Gunderson, C. A., Edwards, N. T., Walker, A. V., O'Hara, K. H., Campion, C. M., \& Hanson, P. J.(2012). Forest phenology and a warmer climate-growing season extension in relation to climatic provenance. Global Change Biol. ,18 , 2008-2025.

Gusewell, S. (2004). N:P ratios in terrestrial plants: variation and functional significance. New Phytol. , $164,243-266$.

Hall, S. J., \& Silver, W. L. (2015). Reducing conditions, reactive metals, and their interactions can explain spatial patterns of surface soil carbon in a humid tropical forest. Biogeochemistry, 125 , 149-165.

Hood, J. M., Benstead, J. P., Cross, W. F., Huryn, A. D., Johnson, P. W., Gislason, G. M., et al.(2018). Increased resource use efficiency amplifies positive response of aquatic primary production to experimental warming. Global Change Biol. , 24 , 1069-1084.

Hou, E., Wen, D., Jiang, L., Luo, X., Kuang, Y., Lu, X., et al.(2021). Latitudinal patterns of terrestrial phosphorus limitation over the globe. Ecol. Lett. DOI: 10.1111/ele.13761.

Huang, W., \& Hall, S. J. (2017). Optimized high-throughput methods for quantifying iron biogeochemical dynamics in soil. Geoderma , 306, 67-72.

Hubau, W., Lewis, S. L., Phillips, O. L., Affum-Baffoe, K., Beeckman, H., Cuni-Sanchez, A., et al. (2020). Asynchronous carbon sink saturation in African and Amazonian. Nature ,579 , 80-87.

Jonasson, S., Castro, J., \& Michelsen, A. (2004). Litter, warming and plants affect respiration and allocation of soil microbial and plant C, N and P in arctic mesocosms. Soil Biol. Biochem. ,36 , 1129-1139.

enzyme activities and protein expression. Biogeosciences ,9 , 4537-4551.

Li, Y., Zhou, G., Huang, W., Liu, J., \& Fang, X. (2016). Potential effects of warming on soil respiration and carbon sequestration in a subtropical forest. Plant Soil , 409, 247-257.

Lie, Z., Huang, W., Liu, X., Zhou, G., Yan, J., Li, Y., et al.(2021). Warming leads to more closed nitrogen cycling in nitrogen-rich tropical forests. Global Change Biol. , 27 , 664-674. 
Lin, Y., Bhattacharyya, A., Campbell, A. N., Nico, P. S., Pett-Ridge, J., \& Silver, W. L. (2018). Phosphorus fractionation responds to dynamic redox conditions in a humid tropical forest soil. J. Geophys. Res-Biogeo. $123,3016-3027$.

Liptzin, D., \& Silver, W. L. (2009). Effects of carbon additions on iron reduction and phosphorus availability in a humid tropical forest soil. Soil Biol. Biochem. , 41, 1696-1702.

Liptzin, D., \& Silver, W. L. (2015). Spatial patterns in oxygen and redox sensitive biogeochemistry in tropical forest soils. Ecosphere, $6,1-14$.

McDowell, R. W., \& Condron, L. M. (2000). ChemicalNature, and potential mobility of phosphorus in fertilized grassland soils. Nutr. Cycl. Agroecosys. 57, 225-233.

McGroddy, M. E., Silver, W. L., de Oliveira Jr, R. C., De Mello, W. Z., \& Keller, M. (2008). Retention of phosphorus in highly weathered soils under a lowland Amazonian forest ecosystem. J. Geophys. Res-Biogeo. 113 , G04012.

Mora, C., Frazier, A. G., Longman, R. J., Dacks, R. S., Walton, M. M., Tong, E. J., et al.(2013). The projected timing of climate departure from recent variability. Nature, 502, 183-187.

Navratil, T., Rohovec, J., Amirbahman, A., Norton, S. A., \& Fernandez, I. J. (2009). Amorphous aluminum hydroxide control on sulfate and phosphate in sediment-solution systems. Water Air Soil Poll., 201 , 87-98.

Nottingham, A. T., Whitaker, J., Ostle, N. J., Bardgett, R. D., McNamara, N. P., Fierer, N., et al. (2019). Microbial responses to warming enhance soil carbon loss following translocation across a tropical forest elevation gradient. Ecol. lett. , 22, 1889-1899.

Nottingham, A. T., Meir, P., Velasquez, E., \& Turner, B. L. (2020). Soil carbon loss by experimental warming in a tropical forest. Nature, $\mathbf{5 8 4}, 234-237$.

Peretyazhko, T., \& Sposito, G. (2005). Iron (III) reduction and phosphorous solubilization in humid tropical forest soils. Geochim. Cosmochim. Ac. 69, 3643-3652.

Reed, S. C., Wood, T., \& Cavaleri, M. A. (2012). Tropical forests in a warming world. New Phytol. , 193 , $27-29$.

Reed, S. C., Yang, X., \& Thornton, P. E. (2015). Incorporating phosphorus cycling into global modeling efforts: a worthwhile, tractable endeavor. New Phytol. , 208 , 324-329.

Ren, H., Kang, J., Yuan, Z., Xu, Z., \& Han, G. (2018). Responses of nutrient resorption to warming and nitrogen fertilization in contrasting wet and dry years in a desert grassland. Plant Soil ,432, 65-73.

Rosling, A., Midgley, M. G., Cheeke, T., Urbina, H., Fransson, P., \& Phillips, R. P. (2016). Phosphorus cycling in deciduous forest soil differs between stands dominated by ecto- and arbuscular mycorrhizal trees. New Phytol. , 209 , 1184-1195.

Rui, Y., Wang, Y., Chen, C., Zhou, X., Wang, S., Xu, Z., et al.(2012). Warming and grazing increase mineralization of organic P in an alpine meadow ecosystem of Qinghai-Tibet Plateau, China. Plant Soil, $357,73-87$.

Sardans, J., \& Penuelas, J. (2012). The role of plants in the effects of global change on nutrient availability and stoichiometry in the plant-soil system. Plant Physiol ., 160, 1741-1761.

Sardans, J., Penuelas, J., \& Estiarte, M. (2006). Warming and drought alter soil phosphatase activity and soil P availability in a Mediterranean shrubland. Plant Soil , 289, 227-238.

Sullivan, M. J., Lewis, S. L., Affum-Baffoe, K., Castilho, C., Costa, F., Sanchez, A. C., et al. (2020). Long-term thermal sensitivity of Earth's tropical forests. Science ,368 , 869-874. 
Sun, X., Kang, H., Chen, H. Y., Bjorn, B., Samuel, B. F., \& Liu, C.et al. (2016). Biogeographic patterns of nutrient resorption from Quercus variabilis Blume leaves across China. Plant Biology , 18 , 505-513.

Sun, Y., Peng, S., Goll, D. S., Ciais, P., Guenet, B., Guimberteau, M., et al. (2017). Diagnosing phosphorus limitations in natural terrestrial ecosystems in carbon cycle models. Earths Future , 5 , 730-749.

Tabatabai, M. A. (1994). Soil enzymes. In: Weaver RW, Angle S, Bottomley P, Bezdicek D, Smith S, Tabatabai A, Wollum A (eds). Methods of soil analysis. Part 2. Microbiological and biochemical properties, SSSA Book Ser, vol 5. SSSA, Madison (pp 801-834).

Tian, D., Reich, P. B., Chen, H. Y., Xiang, Y., Luo, Y., Shen, Y., et al. (2019). Global changes alter plant multi-element stoichiometric coupling. New Phytol. , 221 , 807-817.

Tiessen, H. J. W. B., \& Moir, J. O.(1993). Characterization of available P by sequential extraction. Soil sampling and methods of analysis , 7, 5-229.

Turner, B. L., Brenes-Arguedas, T., \& Condit, R. (2018). Pervasive phosphorus limitation of tree species but not communities in tropical forests. Nature, 555, 367-370.

Vance, E. D., Brookes, P. C., \& Jenkinson, D. S. (1987). An extraction method for measuring soil microbial biomass C. Soil Biol. Biochem., 19, 703-707.

Vergutz, L., Manzoni, S., Porporato, A., Novais, R. F., \& Jackson, R. B. (2012). Global resorption efficiencies and concentrations of carbon and nutrients in leaves of terrestrial plants. Ecol. Monogr. , 82, 205-220.

Vitousek, P. (1982). Nutrient cycling and nutrient use efficiency. The American Naturalist, 119, 553-572.

Wang, H., Holden, J., Spera, K., Xu, X., Wang, Z., Luan, J., et al. (2013). Phosphorus fluxes at the sediment-water interface in subtropical wetlands subjected to experimental warming: a microcosm study. Chemosphere, 90 , 1794-1804.

Wang, Y., Wang, H., He, J. S., \& Feng, X. et al. (2017). Iron-mediated soil carbon response to water-table decline in an alpine wetland. Nat. Commun. , 8 , 15972.

Wieder, W. R., Cleveland, C. C., Smith, W. K., \& Todd-Brown, K. (2015). Future productivity and carbon storage limited by terrestrial nutrient availability. Nat. Geosci .,8 , 441-444.

Wu, T., Liu, S., Lie, Z., Zheng, M., Duan, H., Chu, G., et al.(2020). Divergent effects of a 6-year warming experiment on the nutrient productivities of subtropical tree species. Forest Ecol. Manag .,461 , 117952.

You, C., Wu, F., Yang, W., Xu, Z., Tan, B., Zhang, L., et al.(2018). Does foliar nutrient resorption regulate the coupled relationship between nitrogen and phosphorus in plant leaves in response to nitrogen deposition? Sci. Total Environ. , 645, 733-742.

Yuan, Z. Y., \& Chen, H. Y. (2015). Decoupling of nitrogen and phosphorus in terrestrial plants associated with global changes. Nat. Clim. Change, 5, 465-469.

Yuan, Z. Y., \& Chen, H. Y. (2009). Global-scale patterns of nutrient resorption associated with latitude, temperature and precipitation. Global Ecol. Biogeogr. , 18, 11-18.

Zhang, Z., Wang, H., Zhou, J., Li, H., He, Z., Van Nostrand, J. D. et al. (2015). Redox potential and microbial functional gene diversity in wetland sediments under simulated warming conditions: implications for phosphorus mobilization. Hydrobiologia , 743, 1-235.

Zhang, Z. J, Wang, Z. D., Holden, J., Xu, X. H., Hang W., Ruan J. H., et al. (2012). The release of phosphorus from sediment into water in subtropical wetlands: a warming microcosm experiment. Hydrol. Process. , $26,15-26$.

Zhou, X., Chen, C., Wang, Y., Xu, Z., Han, H., Li, L., \& Wan, S.(2013). Warming and increased precipitation have differential effects on soil extracellular enzyme activities in a temperate grassland. Sci.Total Environ. 
, $444,552-558$.

Zi, H. B., Hu, L., Wang, C. T., Wang, G. X., Wu, P. F., Lerdau, M., \& Ade, L. J. (2018). Responses of soil bacterial community and enzyme activity to experimental warming of an alpine meadow. Eur. J. Soil Sci. , $69,429-438$.

Zong, N., Shi, P., \& Chai, X. (2018). Effects of warming and nitrogen addition on nutrient resorption efficiency in an alpine meadow on the northern Tibetan Plateau. Soil Sci. Plant Nutr. , 64, 482-490.

Zuccarini, P., Asensio, D., Ogaya, R., Sardans, J., \& Penuelas, J. (2020). Effects of seasonal and decadal warming on soil enzymatic activity in a P-deficient Mediterranean shrubland. Global Change Biol. , 26 , 3698-3714.

(a)

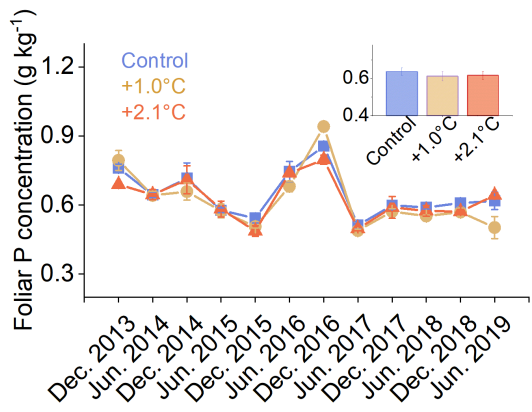

(c)

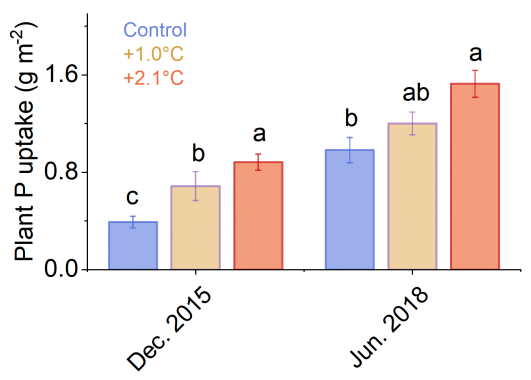

(b)

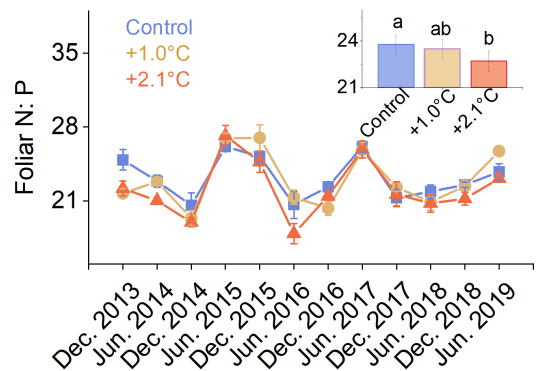

(d)

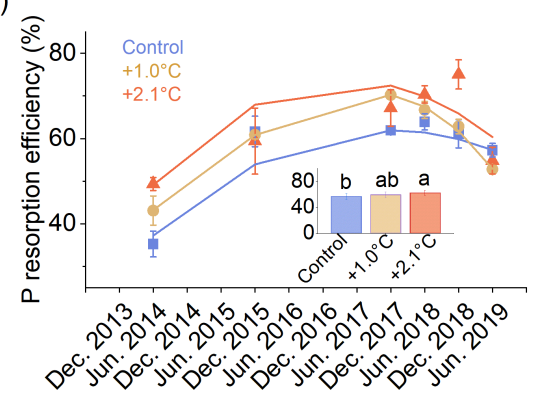

Fig. 1 Effects of warming on plant $\mathrm{P}$ status. Different lowercase letters indicate significant differences among treatments $(P<0.05)$. Error bars indicate standard errors $(\mathrm{n}=3)$.

(a)

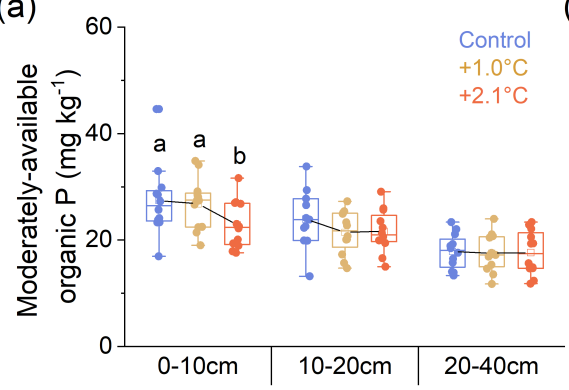

(b)

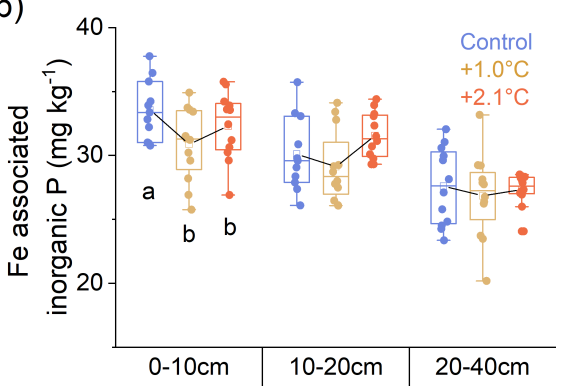

Fig. 2 Effects of warming on moderately-available $\mathrm{P}$ concentrations in three-layer soils $(\mathrm{n}=12)$. Different lowercase letters indicate significant differences among treatments $(P<0.05)$. 
(a)

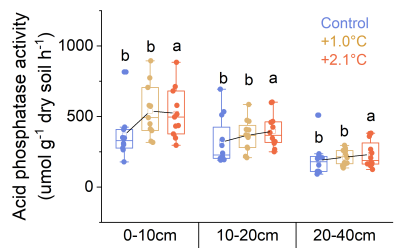

(b)

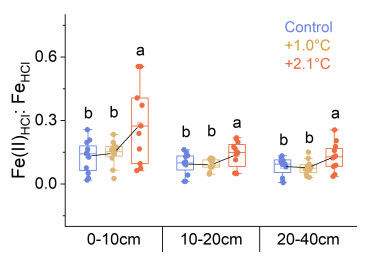

(c)

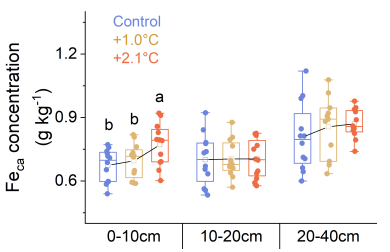

Fig. 3 Effects of warming on acid phosphatase activity (a), ratio of $\mathrm{Fe}(\mathrm{II})$ to total HCl-extractable iron $\left(\mathrm{Fe}_{\mathrm{HCl}}\right)$ (b) and citrate-ascorbate extractable Fe concentrations (c) in three-layer soils $(\mathrm{n}=12)$. Different lowercase letters indicate significant differences among treatments $(P<0.05)$. 

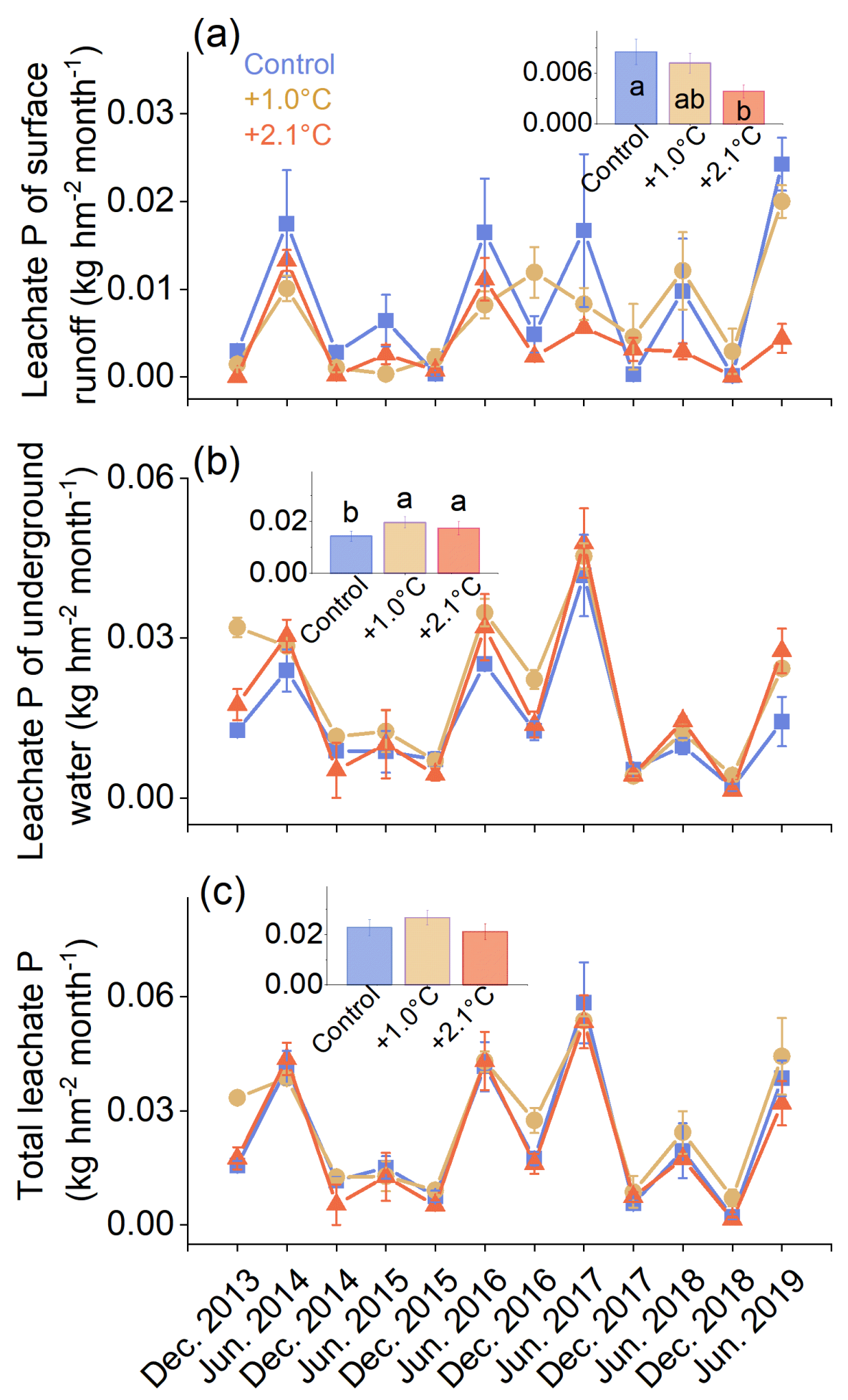

Fig. 4 Effects of warming on leachate $\mathrm{P}$ in surface runoff and underground water, and total $\mathrm{P}$ leachate (both $\mathrm{P}$ in runoff and groundwater). Different lowercase letters indicate significant differences among treatments $(P<0.05)$. Error bars indicate standard errors $(\mathrm{n}=3)$. 


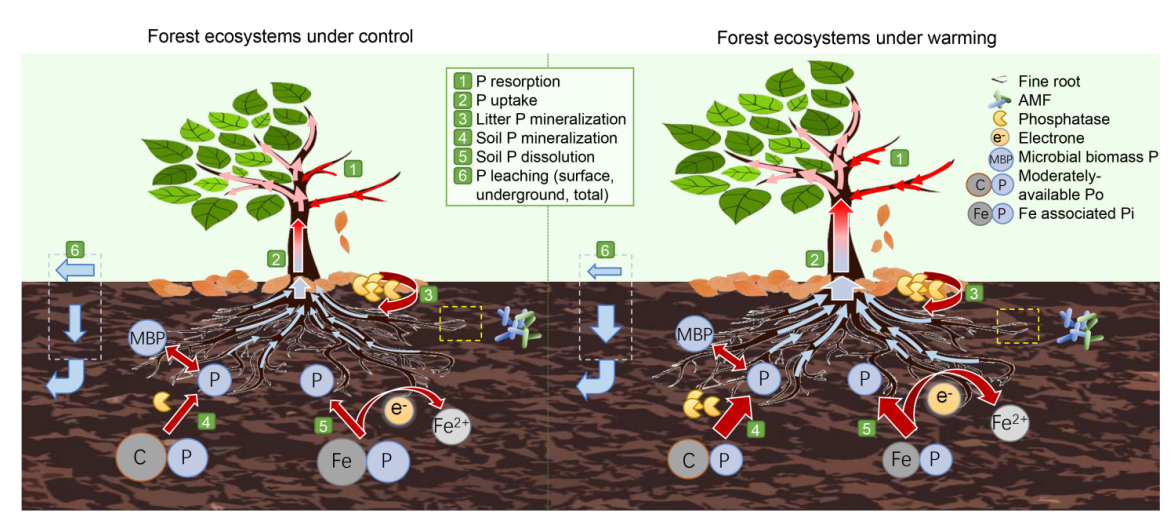

Fig. 5 Schematic showing how the $\mathrm{P}$ cycling links $\mathrm{P}$ demand and $\mathrm{P}$ supply during litter decomposition under control and warming. The increased plant $\mathrm{P}$ uptake (2) with rapid plant growth under warming is supported by the enhanced plant $\mathrm{P}$ resorption (1), soil $\mathrm{P}$ mineralization (4), and $\mathrm{P}$ release from Fe minerals (5) without changing litter $\mathrm{P}$ mineralization (3), total leachate $\mathrm{P}$ (6), fine root and arbuscular mycorrhizal fungi abundance (AMF) within the ecosystems. The enhanced soil P mineralization is associated with the increased phosphatase activity, while the enhanced $\mathrm{P}$ dissolution is indicated by the increase in reduction of Fe concomitantly released Fe associate inorganic $\mathrm{P}$. The increase in released $\mathrm{P}$ is rapidly immobilized by plants but not microbes and results in an equilibrium of soluble P.

Table S1 Effects of warming on soil $\mathrm{pH}$ and bulk density in soil of $0-10 \mathrm{~cm}$ depth, and in-site soil redox potential at $10 \mathrm{~cm}$ depth. The numbers in brackets are standard errors $(\mathrm{n}=3)$. Different lowercase letters indicate significant differences among treatments at $P<0.05$.

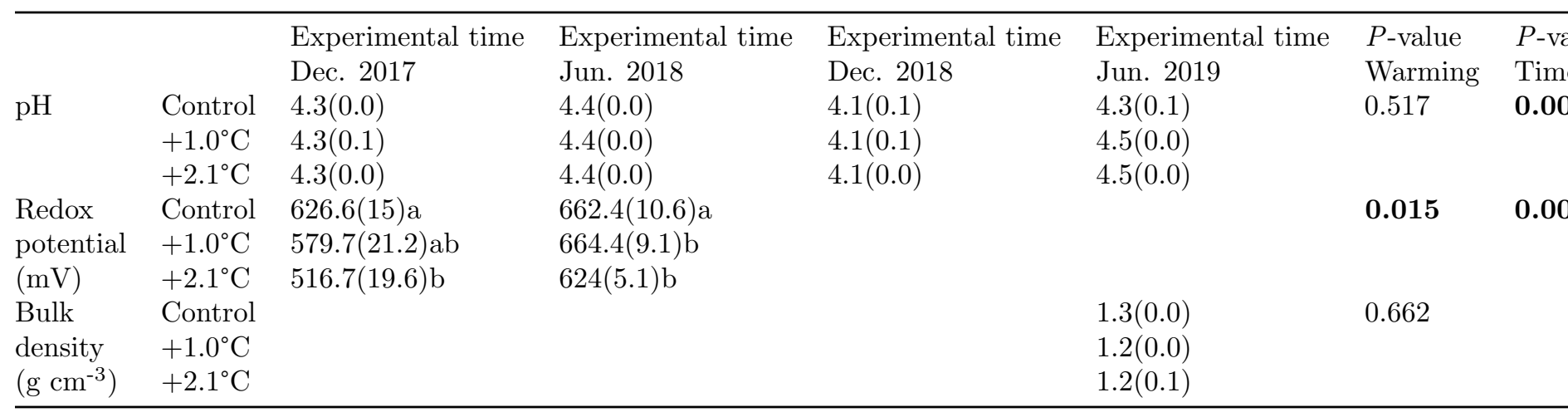

Table S2 Effects of warming on litter $\mathrm{P}$ status The numbers in brackets are standard errors $(\mathrm{n}=3)$. Different lowercase letters indicate significant differences among treatments at $P<0.05$.

\begin{tabular}{lllllll}
\hline & & $\begin{array}{l}\text { Experimental time } \\
\text { Dec. 2017 }\end{array}$ & $\begin{array}{l}\text { Experimental time } \\
\text { Jun. 2018 }\end{array}$ & $\begin{array}{l}\text { Experimental time } \\
\text { Dec. 2018 }\end{array}$ & $\begin{array}{l}\text { Experimental time } \\
\text { Jun. 2019 }\end{array}$ \\
Litter C:P & Control & $1759(76)$ & $1988(120)$ & $1652(120) \mathrm{b}$ & $1314(55)$ \\
& $+1.0^{\circ} \mathrm{C}$ & $2427(51)$ & $2217(120)$ & $1834(132) \mathrm{b}$ & $1454(153)$ \\
& $+2.1^{\circ} \mathrm{C}$ & $2176(332)$ & $2428(269)$ & $2564(332) \mathrm{a}$ & $1094(94)$ \\
Litter P stock & $\mathrm{Control}$ & $9.5(0.6)$ & $10.3(0.7)$ & $10.3(1.1)$ & $9.7(1.5)$ \\
$\left(\mathrm{g} \mathrm{m}^{-2}\right)$ & $+1.0^{\circ} \mathrm{C}$ & $6.9(0.6)$ & $8.8(0.5)$ & $9.3(0.3)$ & $9.8(0.6)$ \\
& $+2.1^{\circ} \mathrm{C}$ & $9.4(0.9)$ & $9.4(0.7)$ & $8.2(1.2)$ & $11(0.4)$ \\
Litter phosphatase & Control & $11043(1008)$ & $5660(781)$ & $7735(2438)$ & $6144(864)$
\end{tabular}




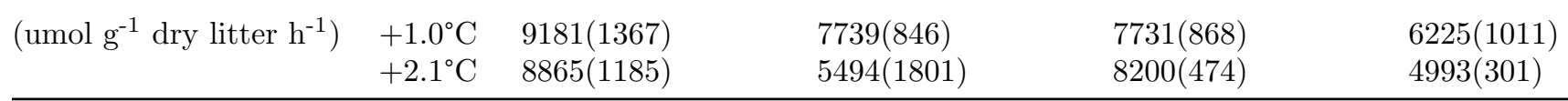

Table S3 Effects of warming on soil $\mathrm{P}$ components in three-layer soils. The values in parentheses represent standard error $(\mathrm{n}=3)$. Al-Pi, Al associated inorganic $\mathrm{P}$; Al-Po, Al associated organic P; Fe-Po, Fe associated organic P; MBP, microbial biomass P. Different lowercase letters indicate significant differences among treatments at $P<0.05$.






\begin{tabular}{|c|c|c|c|c|c|c|c|c|}
\hline \multirow[t]{2}{*}{$\mathrm{Fe}-\mathrm{Po}$} & $0-10$ & Control & $20.1(2)$ & $21.4(0.5)$ & $28.1(1.5) \mathrm{a}$ & $21.8(2.8)$ & 0.079 & 0.962 \\
\hline & $\mathrm{cm}$ & & & & & & & \\
\hline \multirow{10}{*}{$\begin{array}{l}(\mathrm{mg} \\
\left.\mathrm{kg}^{-1}\right)\end{array}$} & & $+1.0^{\circ} \mathrm{C}$ & $16.4(0.1)$ & $24.2(2.5)$ & 27.5(2)ab & $23.4(0.1)$ & & \\
\hline & & $+2.1^{\circ} \mathrm{C}$ & $18.2(3.5)$ & $22(2.2)$ & $19.4(2.3) \mathrm{b}$ & $17.6(1.5)$ & & \\
\hline & $10-20$ & Control & $16(2.4)$ & $23.1(3.9)$ & $23.8(2.5)$ & $21.8(2.2)$ & 0.298 & 0.736 \\
\hline & $\mathrm{cm}$ & & & & & & & \\
\hline & & $+1.0^{\circ} \mathrm{C}$ & $16.9(1.8)$ & $19(2.4)$ & $23(2)$ & $15.7(2.1)$ & & \\
\hline & & $+2.1^{\circ} \mathrm{C}$ & $16.8(2.2)$ & $15.2(1.2)$ & $22(2.7)$ & $20(1.7)$ & & \\
\hline & $20-40$ & Control & $13(0.7)$ & $16.5(1.6)$ & $19.2(1.6)$ & $15.9(1.7)$ & 0.995 & 0.949 \\
\hline & $\mathrm{cm}$ & & & & & & & \\
\hline & & $+1.0^{\circ} \mathrm{C}$ & $13.2(1.7)$ & $14.4(2)$ & $18.3(1.6)$ & $18.3(3.3)$ & & \\
\hline & & $+2.1^{\circ} \mathrm{C}$ & $16.9(2.5)$ & $17.2(2.8)$ & $15.5(2.2)$ & $14.3(2)$ & & \\
\hline \multirow[t]{2}{*}{ MBP } & $0-10$ & Control & $5.4(0.8)$ & & & $4.4(0.7)$ & 0.405 & 0.087 \\
\hline & $\mathrm{cm}$ & & & & & & & \\
\hline \multirow{10}{*}{$\begin{array}{l}(\mathrm{mg} \\
\left.\mathrm{kg}^{-1}\right)\end{array}$} & & $+1.0^{\circ} \mathrm{C}$ & $4.9(1)$ & & & $3.6(1.1)$ & & \\
\hline & & $+2.1^{\circ} \mathrm{C}$ & $4.7(1.3)$ & & & $3.8(1.4)$ & & \\
\hline & $10-20$ & Control & $3.2(2.3)$ & & & $3.6(3.1)$ & 0.080 & 0.569 \\
\hline & $\mathrm{cm}$ & & & & & & & \\
\hline & & $+1.0^{\circ} \mathrm{C}$ & $3.9(0.7)$ & & & $3.4(1.7)$ & & \\
\hline & & $+2.1^{\circ} \mathrm{C}$ & $3.1(2.4)$ & & & $2.3(1.5)$ & & \\
\hline & $20-40$ & Control & $2.9(0.4)$ & & & $3.8(1.2)$ & 0.138 & 0.017 \\
\hline & $\mathrm{cm}$ & & & & & & & \\
\hline & & $+1.0^{\circ} \mathrm{C}$ & $4.1(1.6)$ & & & $4.6(2.6)$ & & \\
\hline & & $+2.1^{\circ} \mathrm{C}$ & $2.7(1.4)$ & & & $6.8(1.4)$ & & \\
\hline
\end{tabular}

Table S4 Effects of warming on soil citrate-dithionite extractable Fe in soil of 0-10 cm depth. The numbers in brackets are standard error $(\mathrm{n}=3)$.

\begin{tabular}{|c|c|c|c|c|c|c|c|}
\hline & Experimental time & Experimental time & Experimental time & Experimental time & $P$-value & $P$-value & $P$-va \\
\hline & Jun. 2014 & Dec. 2015 & Dec. 2017 & Jun. 2018 & Warming & Time & War \\
\hline Control & $37.5(3.6)$ & $33.6(1.7)$ & $36.9(0.3)$ & $29.2(0.5)$ & 0.433 & $<0.001$ & 0.15 \\
\hline$+1.0^{\circ} \mathrm{C}$ & $36.9(1.4)$ & $42.3(3.3)$ & $34.8(2.5)$ & $32(0.8)$ & & & \\
\hline$+2.1^{\circ} \mathrm{C}$ & $39(2.1)$ & $41.6(3.6)$ & $36.2(2)$ & $30.8(0.8)$ & & & \\
\hline
\end{tabular}


(a)

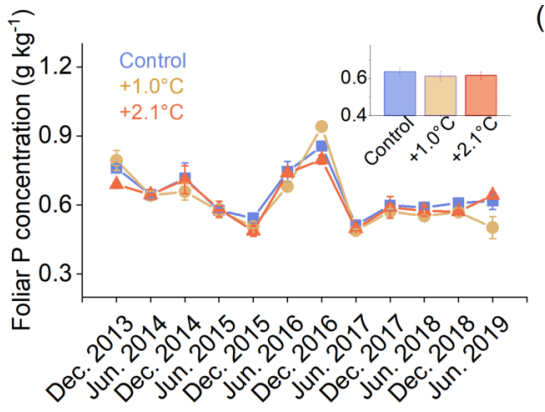

(c)

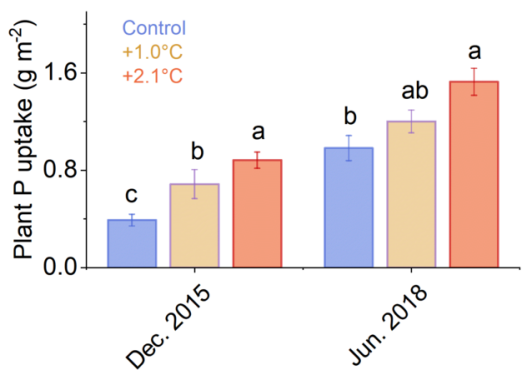

(b)

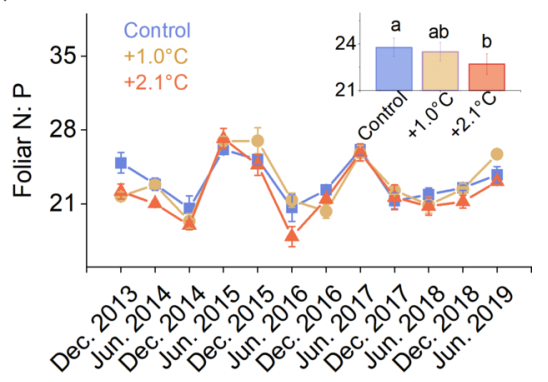

(d)

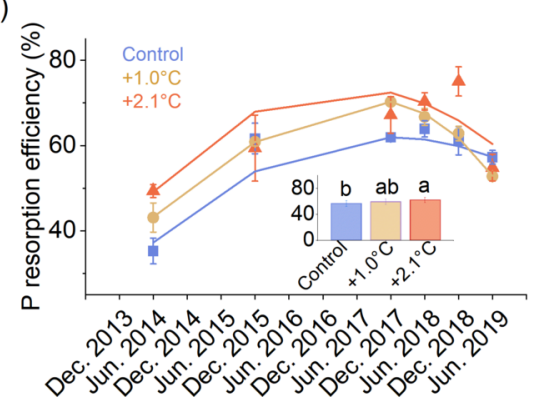

Fig. S1 The scheme of warming experimental design. In order to conduct warming experiment, we used natural temperature differences at three elevations by translocating model forest ecosystems from the highelevation site (control, $600 \mathrm{~m})$ to the two lower-elevation sites $\left(+1.0^{\circ} \mathrm{C}, 300 \mathrm{~m} ;+2.1^{\circ} \mathrm{C}, 30 \mathrm{~m}\right)$.
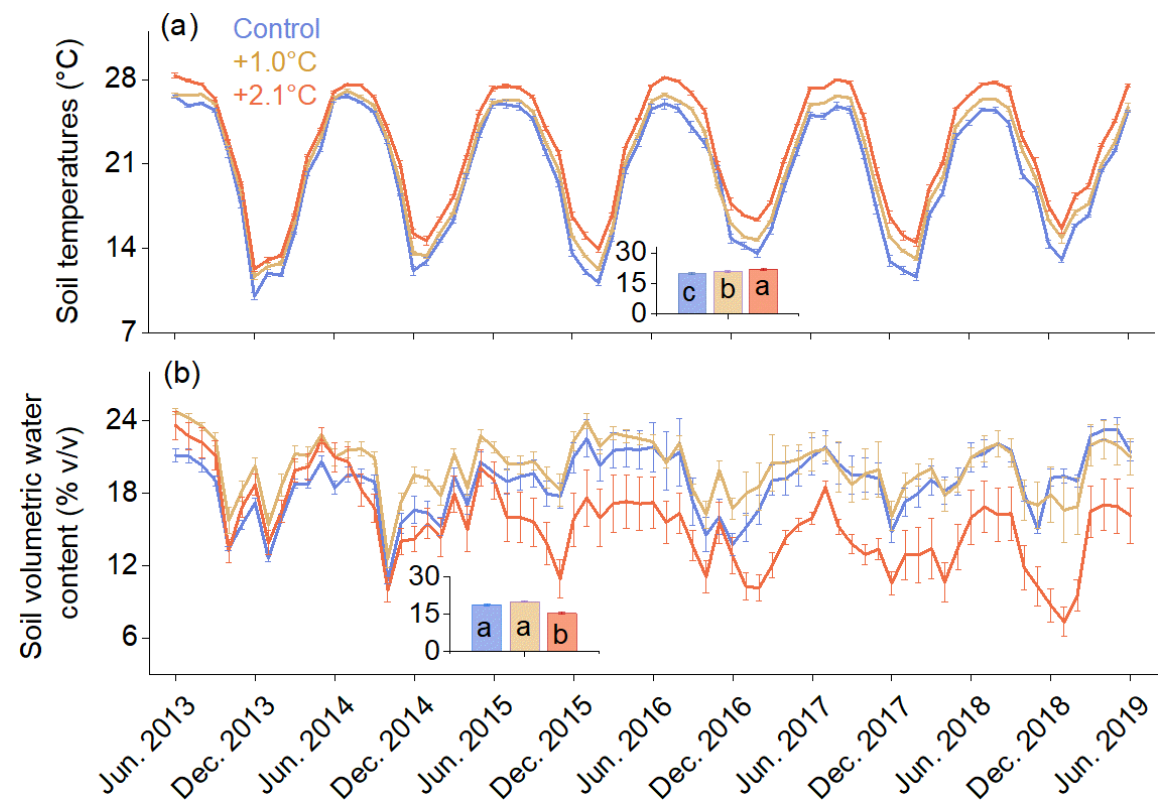

Fig. S2 Effects of warming on soil temperatures and soil moisture on monthly average at $5 \mathrm{~cm}$ depth during 2013-2019. Different lowercase letters indicate significant differences among treatments $(P<0.05)$. Error bars indicate standard errors $(\mathrm{n}=3)$. 

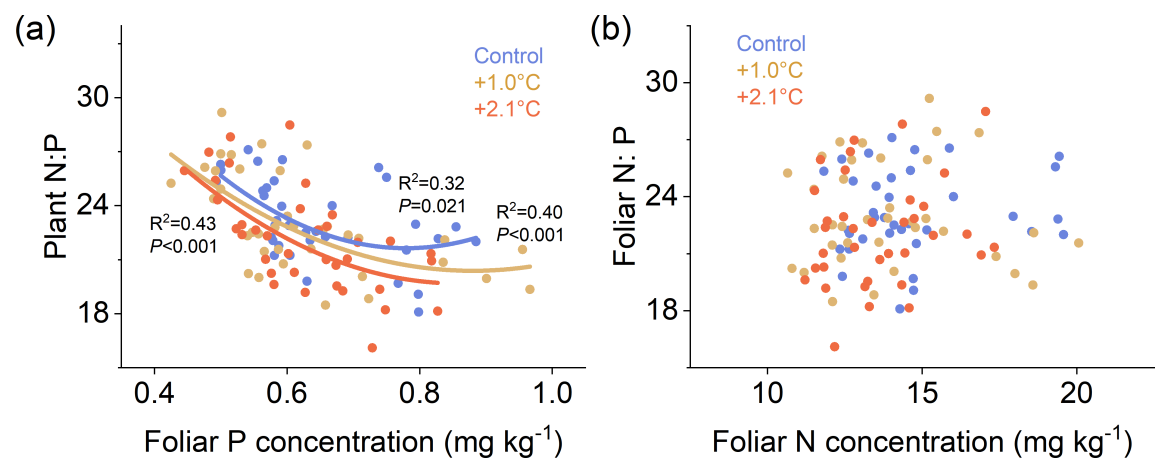

Fig. S3 Relationship between foliar N:P and foliar P and N concentration under control and warming treatments during 2013-2019. 
(a)

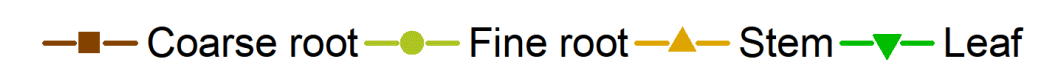

(b)

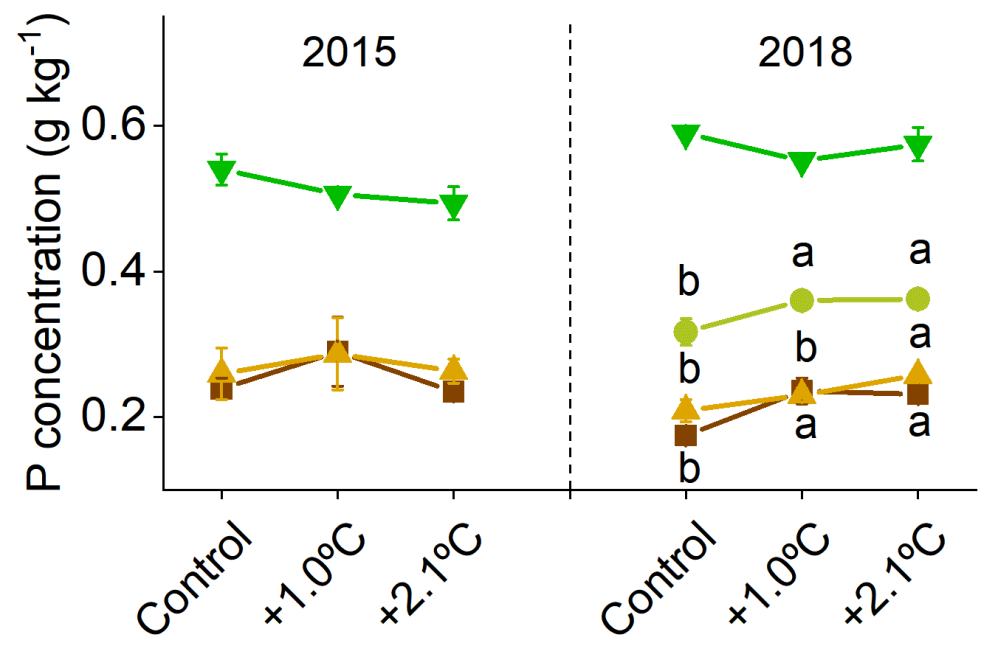

(c)
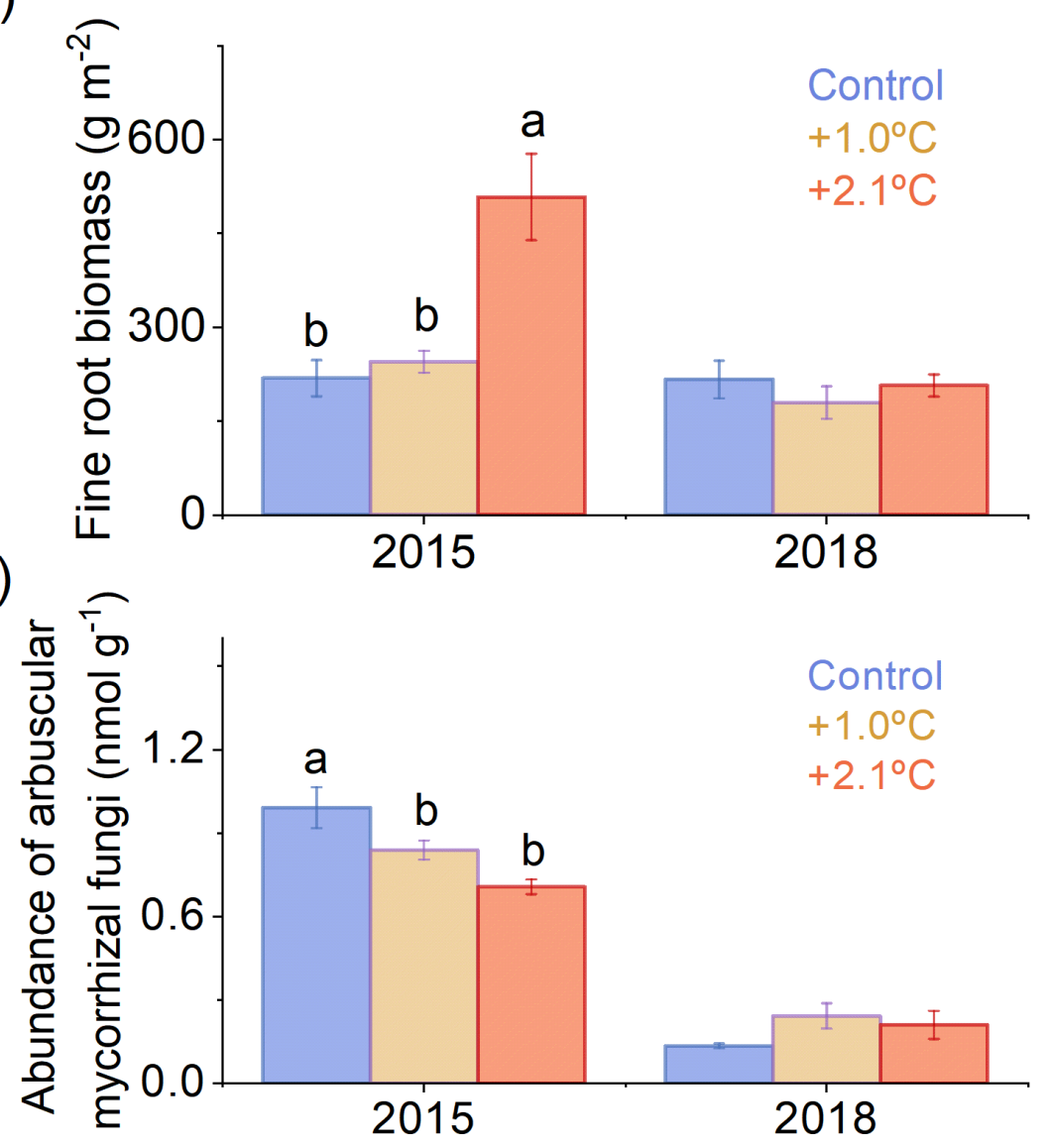

Fig. S4 Effects of warming on plant tissue $\mathrm{P}$ concentration, fine root biomass and abundance of arbuscular mycorrhizal fungi. Different lowercase letters indicate significant differences among treatments $(P<0.05)$. Error bars indicate standard errors $(\mathrm{n}=3)$. 

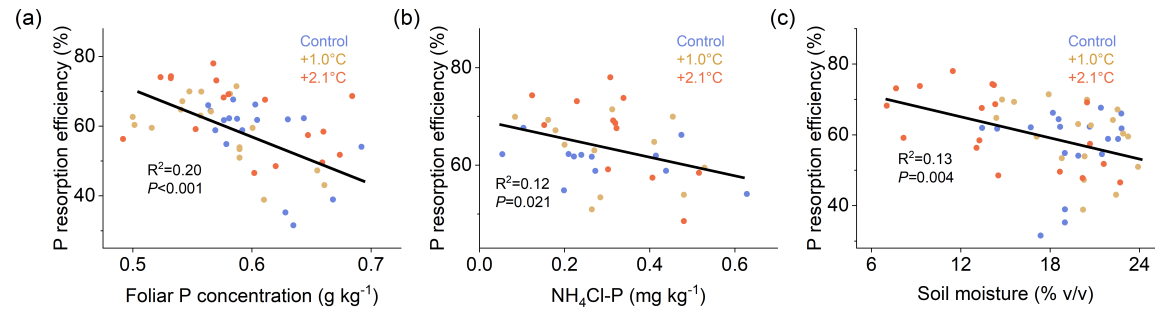

Fig. S5 Relationship between plant resorption efficiency and foliar $\mathrm{P}$ concentrations, $\mathrm{NH}_{4} \mathrm{Cl}-\mathrm{P}$, and soil moisture under control and warming treatments during 2014-2015 and 2017-2019. 